\title{
ANALISIS IMPLEMENTASI PRODUCT IMPROVEMENT INDUSTRI KREATIF DI KOTA MATARAM (STUDI TENTANG INDUSTRI KREATIF SEKTOR KERAJINAN DI KOTA MATARAM)
}

\author{
Emilia Septiani* \\ M. Ilhamuddin* \\ Santi Nururly* \\ Siti Sofiyah*
}

\begin{abstract}
The economic value of a product is not only determined by the raw materials and production process, but it is also determined by creativity and innovation. Creative industry is one of the development concept based on creativity that could potentially increase the economic growth and social welfare. The concept of creative industry itself is creativity-based activities that affect the economy and welfare of the community, where the small industries such as handicrafts is currently widely scattered in various parts of Kota Mataram. The craft center located in Kota Mataram, are cukli, gold / silver, precious stones, weaving, pearl, songket, wood crafts / masks, craft souvenirs and many others. This craft has its own role in the development of the regional economy. The existence of product improvement and creativity that arise in the community makes the creative industries sector in Kota Mataram has an important role in the economic development of the city. The results showed that handicraft producers / entrepreneurs of cukli, gold-pearl, silver, and wood or mask in Kota Mataram has conducted product improvement in various aspects such as functional aspects, aspects of the form until the production aspects. There are several contributing factors for craft producers / entrepreneurs, namely the existence of venture capital assistance either from the bank, the government, even foreign capital; the availability of raw materials, and skilled labor. While the inhibiting factors include the difficulty to improve the quality if the workforce owned is not appropriate in terms of quality, technological limitations in the production process, and the instability of the economy that affect the purchasing power of producers / entrepreneurs to raw material quality.
\end{abstract}

Keywords: Creative Industries, Craft Sector and Product Improvement

\section{Pendahuluan}

\subsection{Latar Belakang}

Untuk meningkatkan pertumbuhan ekonomi dan kesejahteraan masyarakat di Indonesia, pemerintah membuat suatu kebijakan yang mengedepankan sektor industri. Tidak hanya mengandalkan bidang industri sebagai sumber ekonomi negara tetapi juga mengandalkan sumber daya manusia yang kreatif. Nilai ekonomi dari suatu produk selain ditentukan oleh bahan baku dan proses produksi, juga pada pemanfaatan kreativitas dan penciptaan inovasi melalui perkembangan teknologi yang semakin maju.

Industri kreatif sendiri merupakan salah satu hasil pengembangan konsep berdasarkan modal kreatifitas yang berpotensi meningkatkan pertumbuhan ekonomi dan kesejahteraan masyarakat. Pada tahun 2012, geliat industri kreatif di Indonesia semakin menunjukkan perkembangan yang signifikan. Sekarang ini sebagian orang mulai memprediksi pertumbuhan industri kreatif bisa melonjak cukup tinggi yakni

\footnotetext{
${ }^{*}$ Dosen Fakultas Ekonomi dan Bisnis, Universitas Mataram
} 
hingga mencapai tiga kali lipat dibandingkan tahun-tahun sebelumnya. Kondisi ini dapat kita lihat dari pertumbuhan industri kreatif yang semakin hari semakin aktif, sehingga penyerapan tenaga kerja dan kapasitas daya cipta di negara kita mulai merangkak naik dan memberikan dampak yang cukup positif bagi perkembangan ekonomi di Indonesia.

Banyak daerah di Indonesia yang berkembang ekonominya melalui sektor industri dan pariwisata, termasuk Kota Mataram, Provinsi Nusa Tenggara Barat (NTB). Konsep industri kreatif sendiri merupakan aktivitas berbasis kreatifitas yang berpengaruh terhadap perekonomian dan kesejahteraan masyarakat, maka industriindustri kecil seperti kerajinan tangan saat ini banyak tersebar di berbagai penjuru Kota Mataram. Adapun sentra kerajinan yang terdapat di Kota Mataram antara lain cukli, kerajinan emas/perak, batu permata, tenun ikat, mutiara, tenun songket, kerajinan kayu/topeng, kerajinan souvenir dan masih banyak yang lainnya. Kerajinan ini mempunyai peranan tersendiri dalam pengembangan perekonomian daerah. Adanya product improvement dan kreatifitas yang timbul pada masyarakat inilah yang membuat sektor industri kreatif di Kota Mataram mempunyai peran penting dalam pengembangan perekonomian kota.

Product improvement hendaknya menjadi pusat perhatian karena produk yang dihasilkan harus disesuaikan dengan kebutuhan pasar. Produk harus selalu disempurnakan, dimodifikasi dan dikembangkan melalui upaya riset ataupun pengembangan. Riset dan pengembangan produk sangat erat kaitannya dengan keberhasilan dalam usaha meningkatkan penjualan. Dengan melakukan product improvement, maka peluang untuk mendapatkan pelanggan baru akan semakin besar. Ma'arif (2003:84) menyatakan bahwa product improvement adalah suatu usaha yang direncanakan dan dilakukan dengan sadar untuk memperbaiki produk yang ada atau untuk menambah banyaknya ragam produk yang dihasilkan.

Industri kreatif sektor kerajinan merupakan salah satu dari 14 sektor industri kreatif yang diidentifikasi sangat potensial untuk diperbaiki, disempurnakan, dimodifikasi dan dikembangkan oleh Pemerintah Kota Mataram. Lebih-lebih untuk pengembangan sektor ekonomi kreatif ini pemerintah Kota Mataram telah menetapkan industri kerajinan, industri kecil dan menengah sebagai prioritas pembangunan ekonomi jangka panjang (RPJPD Kota Mataram 2005-2025). Untuk itu para pengrajin di Kota Mataram dituntut untuk dapat melakukan product improvement agar produk yang dihasilkannya tetap menarik bagi konsumen maupun konsumen potensial. Namun, tidak semua pengrajin bersedia dan sanggup untuk melakukan product improvement ini dikarenakan berbagai faktor. Oleh karena itu, penelitian ini dilakukan untuk melihat bagaimana penerapan product improvement yang dilakukan oleh para pengrajin serta melihat hambatan dan dukungan apa yang diperoleh para pengrajin untuk mengimplementasikan product improvement ini.

\subsection{Perumusan Masalah}

Berdasarkan latar belakang diatas maka dapat dirumuskan permasalahan sebagai berikut:

1. Bagaimanakah implementasi product improvement industri kreatif sektor kerajinan di Kota Mataram?

2. Apakah faktor pendukung dan penghambat dalam implementasi product improvement industri kreatif sektor kerajinan di kota Mataram?

\subsection{Tujuan dan Kegunaan Penelitian \\ 1.3.1. Tujuan Penelitian}


Penelitian ini bertujuan untuk mengetahui, mendeskripsikan dan menganalisis implementasi product improvement industri kreatif sektor kerajinan di kota Mataram dan menganalisis faktor penghambat dan pendukung yang muncul dalam implementasi product improvement tersebut.

\subsubsection{Kegunaan Penelitian}

Implikasi secara kebijakan adalah Pemerintah Kota Mataram diharapkan dapat merumuskan strategi untuk implementasi product improvement industri kreatif sektor kerajinan agar dapat bersaing dengan produk sejenis dari daerah lain.

\section{TINJAUAN PUSTAKA}

\subsection{Industri Kreatif}

Menurut Departemen Perdagangan RI (2009:5), industri kreatif adalah industri yang berasal dari pemanfaatan kreatifitas, keterampilan, serta bakat individu untuk menciptakan kesejahteraan dan lapangan pekerjaan dengan menghasilkan dan memberdayakan daya kreasi dan daya cipta individu tersebut.

Lingkup dari kegiatan ekonomi kreatif dapat mencakup banyak aspek. Departemen Perdagangan (2008:4) mengidentifikasi setidaknya ada 14 sektor yang termasuk dalam ekonomi kreatif, yaitu Periklanan; Arsitektur; Pasar barang seni; Kerajinan (handycraft); Desain; Fashion; Film, video, dan fotografi; Permainan interaktif; Musik; Seni pertunjukan; Penerbitan dan percetakan; Layanan komputer dan piranti lunak; Radio dan televisi; serta Riset dan pengembangan.

\subsection{Industri kerajinan}

Kegiatan kerajinan merupakan kegiatan kreatif yang berkaitan dengan kreasi, produksi dan distribusi produk yang dibuat dan dihasilkan oleh tenaga pengrajin yang berawal dari desain awal sampai dengan proses penyelesaian produknya, antara lain meliputi barang kerajinan yang terbuat dari: batu berharga, serat alam maupun buatan, kulit, rotan bambu, kayu, logam (emas, perak, tembaga, perunggu, besi), kayu, kaca, porselin, marmer, tanah liat dan kapur.

Produk kerajinan pada umumnya hanya diproduksi dalam jumlah yang relatif kecil (bukan produksi masal). Volume produksi yang dapat dihasilkan oleh kelompok industri kerajinan ini, sangat bergantung pada jumlah dan keahlian tenaga pengrajin yang tersedia, sehingga kelompok industri ini dapat dikategorikan sebagai industri padat karya.

\subsection{Pengertian Product Improvement (Perbaikan Produk)}

Ma'arif (2003:84) menyatakan bahwa perbaikan produk adalah suatu usaha yang direncanakan dan dilakukan dengan sadar untuk memperbaiki produk yang ada atau untuk menambah banyaknya ragam produk yang dihasilkan dan dipasarkan. Salah satu tanggung jawab penting bagian operasi adalah membantu perusahaan mengidentifikasi kebutuhan dan kesempatan secara cermat dan efektif dengan mencari jalan keluar atas pemecahan masalah produk tersebut.

Jadi dapat disimpulkan bahwa perbaikan produk adalah suatu usaha untuk merubah produk agar mampu memenuhi keinginan, kebutuhan, serta selera konsumen berdasarkan perencanaan. 
Menurut Sumayang (2003:14), ada tiga strategi utama dalam perbaikan produk, yaitu:

a. Memperbaiki kualitas (Quality improvement)

Strategi ini bertujuan untuk menaikkan manfaat produk melalui penggunaan barang dan teknik yang lebih baik dan meningkatkan daya guna fungsional dari produk (daya tahan ketepatan).

b. Perbaikan ciri khas (Feature improvement)

Strategi ini bertujuan menaikkan kegunaan dari suatu barang dengan penambahan ciri khas tertentu, misalnya memberikan pengamanan, kesenangan dan efisiensi tertentu. Kebaikan dari strategi ini adalah sering menghasilkan publisitas cuma-cuma dan dapat merupakan alat bersaing yang fleksibel. Kelemahannya adalah mudah ditiru perusahaan lain.

c. Perbaikan bentuk (Desain improvement)

Strategi ini bertujuan menaikkan daya tarik barang, dimana perusahaan akan memilih suatu ciri lain, sehingga akan menguntungkan perusahaan. Kemungkinan yang dapat terjadi adalah perusahaan akan kehilangan konsumen yang lebih menyukai corak lama dan sulitnya untuk mengetahui tentang pembelian konsumen terhadap produk baru tersebut.

\subsection{Peranan Product Improvement Bagi Perusahaan}

Menurut Handoko (2004:180), mengemukakan bahwa setiap perusahaan selalu berusaha untuk dapat bertahan hidup, berkembang dan bersaing. Maka setiap perusahaan selalu menetapkan dan menerapkan strategi dan cara pelaksanaan kegiatan operasinya. Kegiatan operasi yang dilakukan, diarahkan untuk dapat mencapai sasaran perusahaan, yang mana dapat berupa tingkat efisiensi dan efektifitas yang nantinya berimplikasi pada menurunnya biaya produksi dan meningkatnya produktivitas perusahaan.

Oleh karena itu, perusahaan perlu mengadakan perbaikan produk untuk meningkatkan penjualan, tanpa harus mengesampingkan variabel bauran pemasaran lainnya. Bila volume penjualan suatu perusahaan naik, maka keuntungan yang diterima perusahaan akan semakin meningkat.

Pelaksanaan pengembangan produk bertitik tolak pada produk redesain yang dipengaruhi oleh beberapa faktor antara lain: penampilan produk kontruksi, kemampuan produk, tersedianya modal, penggunaannya, hubungan dengan produk sejalur, syarat-syarat service dan desain yang bersaing.

\subsection{Faktor-faktor yang Mempengaruhi Product Improvement}

Menurut Ma'arif (2003:89), faktor-faktor yang mempengaruhi perbaikan produk adalah:

a. Tidak stabilnya posisi persaingan

Supaya perusahaan tidak ketinggalan dari perusahaan pesaing yang telah mengadakan perbaikan produknya, maka perusahaan harus mengikuti untuk mengadakan perbaikan produk.

b. Makin banyaknya variasi penggunaan suatu barang

Dengan semakin banyaknya variasi penggunaan suatu barang menjadi bermacam-macam kegunaan, maka perusahaan harus mengikuti keinginan konsumen tersebut.

c. Pemanfaatan kapasitas produksi

Kapasitas produksi yang belum dimanfaatkan dengan penuh juga merupakan faktor pendorong bagi perbaikan produk. Jika perusahaan 
melihat adanya kesempatan untuk mengisi permintaan pasar, maka sangat menguntungkan jika kapasitas yang belum digunakan secara penuh tadi dimanfaatkan.

d. Munculnya persaingan

Suatu barang yang laku dipasaran, membuat orang lain cenderung memproduksi barang yang sejenis. Untuk itu perusahaam senantiasa memperbaiki hasil produksinya agar tidak kehilangan pasar yang telah ada.

\subsection{Manfaat Product Improvement}

Setiap perusahaan bertujuan untuk meningkatkan penjualan dan meningkatkan kepuasan konsumen dalam mengkonsumsi produk yang dihasilkan. Menurut Sowter (2007:476), manfaat product improvement antara lain:

a. Mempertahankan konsumen pemakai. Agar konsumen tetap memakai produk yang dihasilkan oleh perusahaan, maka perusahaan melakukan perbaikan produk berupa perbaikan mutu dan kualitas, bahan pokok, bahan tambahan dan hiasan. Hal ini menghasilkan produk yang lebih baru dan lebih berguna dibandingkan dengan produk sebelumnya.

b. Merebut konsumen milik pesaing. Tujuan perbaikan produk yaitu supaya produk yang dihasilkan lebih baik dalam hal bentuk, model dan kualitas sehingga mampu bersaing dengan milik pesaing. Jika produk dapat merebut konsumen milik pesaing, hal ini sangat penting bagi peningkatan volume penjualan.

\subsection{Proses Perencanaan Produk}

Perusahaan dapat menentukan apapun jenis dan karakteristik produk yang akan dihasilkan, tetapi yang perlu diperhatikan adalah produk tersebut harus sesuai dengan kebutuahan dan keinginan masyarakat. Karena konsumen hanya mencari dan membeli produk yang sesuai dengan kebutuhan dan keinginannya. Jadi dapat dikatakan produk yang diminati konsumen adalah jalan utama bagi perusahaan untuk tetap eksis dan berkembang.

Agar produk yang dihasilkan perusahaan disukai dan dicari konsumen, maka sebelum diproduksi secara masal, perusahaan perlu merencanakannya dengan baik, inilah yang dinamakan perencanaan produk. Perencanaan produk sebenarnya bukan hanya diperlukan bagi perusahaan yang baru akan beroperasi tetapi juga bagi perusahaan yang sudah berjalan, terutama untuk memperbaiki produk yang telah diproduksi terdahulu.

\subsection{Pembuatan Rancangan}

Pembuatan rancangan ini terdiri dari dua tahap, yaitu rancangan awal (preeliminary design) dan rancangan akhir (final design) produk. Rancangan awal adalah kegiatan menciptakan desain pendahuluan (awal), membuat prototype, penyempurnaan desain, sampai dengan uji coba produk. Sedangkan rancangan akhir kegiatannya hanya untuk menyaring, mendokumentasi dan mendetailkan kembali apa yang sudah dilakukan pada desain pendahuluan.

\section{METODE PENELITIAN}

\subsection{Jenis penelitian} deskriptif.

Jenis penelitian yang digunakan dalam penelitian ini adalah penelitian 


\subsection{Lokasi Penelitian}

Penelitian ini dilakukan di Kota Mataram dengan objek penelitian para pengusaha produk kerajinan, baik itu kerajinan cukli, perak, emas-mutiara, dan kerajinan kayu/topeng. Alasan dipilihnya Kota Mataram sebagai lokasi penelitian karena terdapat keragaman produk kerajinan yang tersebar di wilayah ini.

\subsection{Teknik dan Alat Pengumpulan Data}

Data yang diperlukan dalam penelitian ini dikumpulkan dengan cara angket/kuesioner, wawancara dan dokumentasi.

\subsection{Responden Penelitian}

Populasi dalam penelitian ini adalah para pengusaha produk kerajinan yang tersebar di wilayah Kota Mataram. Oleh karena jumlah populasi tidak diketahui secara pasti maka penentuan sampelnya ditentukan secara non-probability sampling dengan teknik pengambilan sampelnya adalah purposive sampling. Purposive sampling merupakan teknik pengambilan sampel yang dilakukan atas dasar kriteria tertentu. Dalam penelitian ini kriteria sampelnya adalah para pengusaha yang sudah menekuni usahanya lebih dari 3 tahun, telah melaksanakan product improvement atas produk yang dihasilkan, dan berlokasi di Kota Mataram. Untuk jumlah sampel dalam peneltian ini adalah 35 pengusaha. Jumlah ini merujuk pada pendapat Roscoe (1975, dalam Sekaran 2006) yang mengatakan bahwa ukuran sampel lebih dari 30 dan kurang dari 500 adalah tepat untuk kebanyakan penelitian.

\subsection{Jenis Data dan Sumber data}

Jenis data yang digunakan dalam penelitian ini adalah data kuantitatif dan data kualitatif. Adapun data yang dikumpulkan dalam penelitian ini bersumber dari data primer dan data sekunder yang diperoleh dari Badan Pusat Statistik Kota Mataram.

\subsection{Identifikasi Variabel}

Berkaitan dengan tujuan penelitian, yaitu untuk mengetahui pelaksanaan perbaikan produk yang dilakukan oleh para pengrajin yang dilihat dari proses produksi, maka variabel yang akan diteliti adalah:

1. Aspek fungsional

Aspek fungsional adalah kegunaan dari produk kerajinan yang akan dibuat atau menyangkut tentang bagaimana produk kerajinan dapat berfungsi oleh pengusaha kerajinan di Kota Mataram.

2. Aspek bentuk

Aspek bentuk lebih mengarah pada penentuan fisik produk kerajinan para pengusaha kerajinan di Kota Mataram. Dalam mendesain bentuk, selera pasar, image dan kepentingan-kepentingan individu perlu diperhatikan. Bentuk lebih memberikan kontribusi dalam hal kegunaan dan juga penampilannya.

3. Aspek produksi

Aspek produksi menitikberatkan pada bagaimana pengusaha kerajinan di Kota Mataram mampu membuat produk dengan mudah dan dengan biaya yang rendah atau murah.

\subsection{Teknik Analisa}

Analisa data dalam penelitian ini menggunakan tabulasi sebagai salah satu alat analisis statistik untuk penelitian deskriptif, yang terdiri dari tabulasi frekuensi dan 
tabulasi silang. Analisis tabulasi yang dilakukan menggunakan program SPSS 17 (Statistiscal Package For Social Science).

\section{HASIL DAN PEMBAHASAN}

Setiap pengusaha produk kerajinan yang ada di Kota Mataram, baik itu pengusaha produk kerajinan cukli, emas-mutiara, perak dan kayu atau topeng, memerlukan bahan mentah (bahan baku dan bahan penolong) serta peralatan atau mesin untuk menghasilkan produk kerajinan yang memiliki daya jual. Setiap pengusaha produk kerajinan tersebut masih mempertahankan cara tradisional dalam pembuatan produk kerajinan. Sekalipun ada penggunaan mesin, hal itu hanya sebatas mesin semi modern yang biasanya digunakan untuk sekedar memotong bahan baku seperti kayu. Kegiatan proses produksi yang masih mempertahankan cara tradisional ini bukan karena pengusaha dan/atau pengrajin produk kerajinan yang ada di Kota Mataram tertutup terhadap perkembangan teknologi, melainkan karena bahan baku yang digunakan untuk memproduksi produk-produk kerajinan berbahan baku emas 22 karat dan perak tidak dapat diolah dengan menggunakan mesin. Meskipun masih buatan tangan, produk kerajinan yang dihasilkan oleh para pengusaha tersebut tetap terjaga kualitasnya. Sehingga dari segi proses produksi, tidak banyak pengembangan atau perbaikan yang dilakukan.

Meskipun demikian, bukan berarti para pengusaha produk kerajinan yang ada di Kota Mataram tidak melakukan pengembangan atau perbaikan terhadap produk yang dihasilkannya. Sebagian pengusaha produk kerajinan terlihat melakukan perbaikan dari berbagai aspek, mulai dari aspek fungsional, aspek bentuk, dan aspek produksi. Dari aspek fungsional, para pengusaha melakukan beberapa hal seperti perbaikan fungsi atau kegunaan dari produk kerajinan yang dihasilkan sehingga produk kerajinan tersebut selain dapat memberikan manfaat langsung juga dapat memberikan manfaat tak langsung. Misalkan untuk produk kerajinan cukli berupa kursi, selain dapat digunakan untuk duduk, produk tersebut juga dapat digunakan untuk menghias ruangan karena memiliki unsur etnik yang kental. Kualitas juga tidak luput dari perhatian para pengusaha ini. Kualitas merupakan hal terpenting untuk menghasilkan produk yang diminati oleh masyarakat. Kualitas tidak hanya melekat pada produk jadi, melainkan kualitas bahan baku ataupun bahan penolong yang digunakan menjadi tolak ukur dari kualitas produk jadi tersebut.

Selain aspek fungsional, para pengusaha produk kerajinan di Kota Mataram juga melakukan perbaikan produk yang dihasilkan dari aspek bentuk agar produk kerajinan yang dihasilkannya memiliki bentuk yang lebih baik atau sempurna. Perbaikan bentuk, perbaikan ukuran, model dan modifikasi warna juga menjadi hal yang cukup diperhatikan oleh para pengusaha. Perbaikan dari aspek bentuk ini bertujuan agar konsumen memiliki lebih banyak pilihan produk dan dapat sesuai dengan karakteristik konsumen tersebut. Misalkan untuk produk mutiara, saat ini konsumen lebih menyukai bentuk mutiara yang tidak bulat sempurna dengan warna mutiara hitam. Saat ini memang sudah cukup banyak pilihan warna mutiara. Mutiara yang berwarna-warni ini diperoleh dengan cara injeksi pada proses pengembangbiakan mutiara. Untuk warna mutiara selain hitam, para pengusaha lokal sudah dapat melakukannya sendiri. Namun untuk mutiara hitam diperoleh dari wilayah Tahiti, Hawaii. Model produk kerajinan pun saat ini semakin beragam. Model tidak lagi hanya ditentukan oleh kemampuan dari para pengrajin atau sesuai dengan icon daerah, tetapi juga mengambil contoh dari produk-produk lain dari berbagai daerah. Bahkan tidak jarang konsumen membawa contoh design sendiri. 
Untuk aspek produksi, lebih dari 50\% pengusaha produk kerajinan yang ada di Kota Mataram melakukan penyederhanaan bentuk terhadap produk yang dihasilkannya. Hal ini dilakukan dengan harapan agar proses pembuatannya dapat menjadi lebih mudah dan tidak mengalami kesuliatan pada saat pembuatan design awal atau contoh produk. Meskipun demikian, tetap ada beberapa pengusaha yang tidak melakukan penyederhanaan bentuk dengan alasan mempertahankan estetika dari produk tersebut. Baik para pengusaha atau konsumen saat ini memang masih memegang prinsip bahwa semakin rumit suatu produk tersebut dibuat, maka nilai dari produk tersebut semakin tinggi. Sisi lain dari aspek produksi yang disoroti dalam penelitian ini adalah pembuatan rancangan produk secara paket. Lebih dari $90 \%$ pengusaha produk kerajinan yang ada di Kota Mataram ini melakukan rancangan produk secara paket. Alasannya adalah dengan melakukan rancangan secara paket maka akan semakin banyak produk jadi yang siap di jual ke konsumen. Selain itu, dengan melakukan rancangan secara paket maka biaya produksi dapat diminimalkan karena bahan baku yang dibeli pasti dalam jumlah besar sehingga harga dapat dikurangi oleh pemasok. Meskipun para pengusaha ini melakukan rancangan secara paket, tapi jumlah produk kerajinan yang dihasilkannya tetap dalam jumlah wajar. Rancangan secara paket umumnya hanya dilakukan untuk variasi ukuran produk kerajinan. Dengan kata lain satu model produk kerajinan, memiliki beberapa ukuran yang berbeda. Namun demikian, ada pula beberapa pengusaha yang tidak melakukan rancangan secara paket karena sengaja membatasi produk kerajinan yang dihasilkan. Tujuan dari pengusaha ini adalah eksklusifitas. Umumnya para pengusaha ini lebih cenderung menerima pesanan langsung dari konsumen sehingga design langsung disesuaikan dengan kebutuhan dan keinginan konsumennya.

Oleh karena itu terlihat bahwa sebagian besar pengusaha produk kerajinan, baik itu cukli, emas-mutiara, perak, dan topeng atau kayu, telah melakukan beberapa perbaikan dibeberapa aspek. Tujuan akhir dari segala perbaikan yang dilakukan ini adalah untuk membuat produk yang dihasilkannya menjadi lebih menarik, lebh variatif, dan lebih berkualitas. Kegiatan perbaikan atau pengembangan produk kerajinan yang dilakukan oleh para pengusaha ini tidak luput dari faktor pendukung dan penghambat baik dari internal maupun eksternal. Faktor pendukung para pengusaha sehingga dapat melakukan product improvement ini adalah sebagai berikut:

a. Modal. Para pengusaha produk kerajinan mengakui bahwa segala kegiatan yang mereka lakukan sejauh ini tidak dapat lepas dari modal. Pengusaha memeperoleh modal dari berbagai sumber. Sebagian besar menggunakan modal awal dari dana pribadi yang dimiliki karena pada saat memulai usaha, skala usahanya masih kecil. Namun seiring dengan bertambahnya permintaan atas produk kerajinan yang mereka hasilkan itu, baik dari dalam maupun luar negeri, para pengusaha mulai mencari bantuan dana. Sumber utama modal selain modal sendiri adalah modal pinjaman yang diperoleh dari bank ataupun bantuan langsung dari pemerintah. Seperti diketahui bahwa beberapa tahun belakangan ini pemerintah Indonesia mengeluarkan berbagai kebijakan untuk membantu para pengusaha industri produk kreatif. Selain itu, modal juga dapat diperoleh dari pihak asing. Hal ini dapat dilihat dari adanya pengusaha produk kerajinan yang ada di Kota Mataram ini berasal dari luar Indonesia (Jepang), sehingga pengusaha tersebut dapat menambah modal usahanya yang bersumber dari koleganya yang berada di negara asalnya. Modal yang dimiliki oleh para pengusaha ini umumnya banyak digunakan untuk pembelian bahan 
baku, penarikan atau pembayaran tenaga kerja, dan juga menambah atau membangun aset.

b. Tenaga Kerja. Tenaga kerja yang jumlah dan kualitasnya sesuai dengan kebutuhan pasti akan membuat suatu kegiatan usaha berjalan dengan baik, lancar, dan mampu berkembang di masa yang akan datang. Oleh karena itu para pengusaha produk kerajinan yang ada di Kota Mataram cukup selektif dalam memilih tenaga kerja yang dalam hal ini adalah pengrajin agar produk yang dihasilkannya memiliki kualitas yang baik. Bahkan sebagian besar dari pengusaha tersebut mempekerjakan orang-orang yang berasal dari lingkungan keluarga dengan alasan lebih mudah dalam melakukan pengawasan pekerjaan dan sebagian besar anggota keluarga memang dipersiapkan untuk ikut serta dalam kegiatan usaha tersebut. Misalnya untuk pengusaha emas-mutiara yang mempekerjakan keluarga mulai dari penjaga toko, designer perhiasan, sampai ke pengrajin emasnya. Untuk pengrajin emas, mereka mengakui jika memiliki anak laki-laki yang baru lulus sekolah menengah pasti langsung diajarkan untuk menjadi pengrajin. Dengan harapan jika usaha tersebut sudah beralih ke generasi berikutnya, mereka sudah mengetahui seluk-beluk usaha yang mereka jalankan.

c. Bahan Baku. Bahan baku merupakan unsur yang terpenting dalam melakukan suatu kegiatan produksi. Bahkan penggunaan bahan baku yang tepat menjadi faktor penentu kualitas produk jadi akhir. Dari segi pasokan bahan baku, sebagian besar pengusaha produk kerajinan cukli, emas-mutiara, perak dan topeng atau kayu tidak mengalami kesulitan untuk memperolehnya. Hal ini dikarenakan Pulau Lombok cukup kaya akan sumber daya alam yang menjadi bahan baku produk kerajinan tersebut. Untuk produk mutiara, mutiara laut Lombok sudah menjadi icon di seluruh Indonesia bahkan sampai ke luar negeri. Hanya untuk produk kayu yang terkadang harus mendapatkan pasokan dari luar Pulau Lombok karenan keterbatasan jenis kayu untuk membuat produk kerajinan.

Adapun faktor penghambat dilaksanakannya product improvement oleh para pengusaha produk kerajinan yang ada di Kota Mataram adalah sebagai berikut:

a. Kualitas Produksi. Sebagian besar pengusaha produk kerajinan yang ada di Kota Mataram masih menggunakan cara-cara tradisional untuk berproduksi. Sebagian besar kegiatannya hanya memanfaatkan tenaga dan keterampilan manusia. Setiap manusia memiliki perbedaan kreativitas dan keterampilan yang membuat munculnya perbedaan kualitas hasil produksi kerajinan jika dilakukan oleh beberapa tenaga kerja yang berbeda meskipun bahan baku serta model yang disyaratkan sama. Oleh karena itu, para pengusaha berusaha meminimalkan hal ini dengan cara membagi pekerjaan dengan cara spesialisasi. Dengan demikian, para pengrajin yang dipekerjakan akan melakukan pekerjaan sesuai dengan keahlian yang dimiliki. Namun spesialisasi ini cukup sulit untuk dipertahankan jika sedang banyak pesanan atau permintaan akan produk kerajinan, terutama yang berbahan baku kayu sehingga semua tenaga kerja yang dimiliki oleh para pengusaha tersebut dituntut untuk dapat melakukan semua jenis pekerjaan agar dapat memenuhi pesanan tepat waktu dengan pengawasan penuh dari tenaga kerja yang memang spesialis dibidangnya atau bahkan pengusaha yang bersangkutan.

b. Teknologi. Sebagian besar para pengusaha produk kerajinan yang ada di Kota Mataram saat ini masih menggunakan cara tradisional dalam menghasilkan produk kerajinan. Pada dasarnya penggunaan cara tradisional ini tidak terlalu 
memberikan dampak yang signifikan terhadap lamanya proses produksi yang dilakukan. Hanya saja jika pengusaha menerima pesanan dalam jumlah yang cukup banyak, waktu pengerjaan produk kerajinan tersebut akan menjadi sangat lama.

c. Kondisi Perekonomian. Semakin baik kondisi perekonomian suatu negara, maka diharapkan daya beli masyarakat semakin baik pula. Demikian juga di Indonesia. Ketidakstabilan ekonomi sangat mempengaruhi daya beli pengusaha produk kerajinan yang ada di Kota Mataram terhadap bahan baku yang digunakan untuk membuat produk kerajinan tertentu. Misalnya pengusaha membeli bahan baku produk kerajinan pada saat nilai mata uang melemah sehingga harga bahan baku meningkat. Peningkatan harga bahan baku ini akan mempengaruhi daya beli pengusaha untuk mempertahankan pembelian bahan baku yang berkualitas. Sehingga jika peningkatan harga bahan baku meningkat secara signifikan, sebagian besar pengusaha memilih untuk menyederhanakan proses produksi dan mencari bahan baku pengganti yang tidak menutup kemungkinan kualitasnya berada sedikit di bawah standar yang biasa digunakan. Bahkan ada juga pengusaha yang hanya menerima pesanan jika hal tersebut terjadi.

\section{KESIMPULAN DAN SARAN}

\subsection{Kesimpulan}

Dari uraian pembahasan dapat ditarik kesimpulan penting, yaitu:

1. Para pengusaha produk kerajinan, baik itu kerajinan cukli, emas-mutiara, perak, dan kayu atau topeng telah melakukan product improvement dalam beberapa aspek mulai dari aspek fungsional, aspek bentuk sampai aspek produksi. Dari aspek fungsional, para pengusaha melakukan beberapa hal seperti perbaikan fungsi atau kegunaan dari produk kerajinan yang dihasilkan sehingga produk kerajinan tersebut selain dapat memberikan manfaat langsung juga dapat memberikan manfaat tak langsung. Kualitas juga tidak luput dari perhatian para pengusaha ini. Kualitas merupakan hal terpenting untuk menghasilkan produk yang diminati oleh masyarakat. Kualitas tidak hanya melekat pada produk jadi, melainkan kualitas bahan baku ataupun bahan penolong yang digunakan menjadi tolak ukur dari kualitas produk jadi tersebut. Selain aspek fungsional, para pengusaha produk kerajinan di Kota Mataram juga melakukan perbaikan produk yang dihasilkan dari aspek bentuk agar produk kerajinan yang dihasilkannya memiliki bentuk yang lebih baik atau sempurna. Perbaikan bentuk, perbaikan ukuran, model dan modifikasi warna juga menjadi hal yang cukup diperhatikan oleh para pengusaha. Untuk aspek produksi, lebih dari 50\% pengusaha produk kerajinan yang ada di Kota Mataram melakukan penyederhanaan bentuk terhadap produk yang dihasilkannya. Selain itu, lebih dari $90 \%$ pengusaha produk kerajinan yang ada di Kota Mataram ini melakukan rancangan produk secara paket. Dengan demikian para pengusaha produk kerajinan yang ada di Kota Mataram telah mengimplemntasikan product improvement terhadap produk kerajinan yang dihasilkannya.

2. Di dalam pengimplementasian product improvement ini terdapat beberapa faktor pendukung bagi para pengusaha, yaitu adanya bantuan modal usaha baik dari bank, pemerintah, bahkan modal asing. Untuk modal, saat ini para pengusaha diberi kemudahan untuk memperolehnya dengan adanya beberapa kebijakan dari pemerintah untuk membantu menumbuhkembangkan industri kreatif 
yang ada di Kota Mataram. Selain modal, faktor pendukung lainnya adalah ketersediaan bahan baku dan tenaga kerja yang cukup terampil sehingga dapat memperlancar kegiatan proses produksi produk kerajinan, baik itu kerajinan cukli, emas-mutiara, perak, dan kayu atau topeng yang dilakukan oleh para pengusaha di Kota Mataram. Meskipun demikian, faktor penghambat dalam pengimplementasian product improvement juga tidak dapat diabaikan. Faktor penghambat ini terkait dengan sulitnya melakukan perbaikan kualitas jika tenaga kerja yang dimiliki tidak sesuai dari segi kualitas, keterbatasan teknologi dalam proses produksi, dan ketidakstabilan perekonomian sehingga mempengaruhi daya beli pengusaha terhadap bahan baku yang berkualitas.

\subsection{Saran}

Adapun saran yang dapat diberikan kepada para pengusaha produk kerajinan, baik produk kerajinan cukli, emas-mutiara, perak, dan kayu atau topeng, yang ada di Kota Mataram adalah sebagai berikut:

1. Pada dasarnya implementasi product improvement yang dilakukan oleh pengusaha produk kerajinan yang ada di Kota Mataram sudah cukup baik. Hal ini terbukti dengan hasil penelitian yang menunjukkan bahwa sebagian besar pengusaha produk kerajinan di Kota Mataram telah melakukan product improvement di berbagai aspek, mulai dari aspek fungsional, aspek bentuk, dan aspek produksi. Maka dari itu, para pengusaha harus mempertahankan bahkan meningkatkan lagi pengimplementasian product improvement.

2. Bagi para pengusaha produk kerajinan yang ada di Kota Mataaram yang belum melakukan product improvement di setiap aspek, sebaiknya tidak perlu ragu untuk melakukannya. Hal ini dikarenakan pengimplementasian product improvement dengan maksimal akan mengakibatkan peningkatan yang positif dalam hal produksi, baik dalam hal kuantitas maupun kualitas.

3. Para pengusaha produk kerajinan yang ada di Kota Mataram harus benar-benar memanfaatkan dukungan dari berbagai aspek untuk mendukung kegiatan implementasi product improvement terhadap produk kerajinan yang dihasilkannya.

4. Adanya faktor penghambat jangan dijadikan sebagai ganjalan dalam pengimplementasian product improvement. Para pengusaha produk kerajinan yang ada di Kota Mataram harus dapat merubah hambatan-hambatan tersebut menjadi tantangan untuk dapat lebih baik lagi kedepannya.

\subsection{Keterbatasan dan Arah Penelitian Kedepan}

Adapun keterbatasan dari penelitian ini dan arahan untuk penelitian kedepannya adalah sebagai berikut:

1. Di dalam penelitian ini tidak mempertimbangkan informasi dari pemerintah terkait dengan wujud dukungan dalam pengembangan produk kerajinan yang dihasilkan oleh para pengusaha yang ada di Kota Mataram. Padahal cukup banyak program-program yang dijalankan oleh pemerintah untuk mengembangkan para pengusaha produk kerajinan, selain dari aspek permodalan.

2. Penelitian ini hanya melihat 3 aspek operasional meliputi aspek fungsional, aspek bentuk, dan aspek produksi. Sedangkan aspek perbaikan feature tidak disertakan. Hal ini dikarenakan berdasarkan studi pendahuluan tidak teridentifikasinya pengusaha produk kerajinan yang ada di Kota Mataram memiliki ciri khas atas produk kerajinan yang dihasilkannya. Dengan kata lain, 
design yang dimiliki oleh para pengusaha merupakan design yang juga telah banyak digunakan oleh para pengusaha lainnya.

\section{DAFTAR PUSTAKA}

Adam Everett E and Ebert Ronald J. 2001. Production and Operations Management. Englewood Cliffs NY: Prentice Hall.

Ahyari, Agus. 2002. Manajemen Produksi dan Perencanaan Sistem Produksi, Edisi 4. Yogyakarta: BPFE Yogyakarta.

Anonim. 2005. RPJPD Kota Mataram 2005-2025. http://www.bps.go.id diunduh 11 Maret 2015

Arikunto, Suharsimi. 2005. Prosedur Penelitian Suatu Praktek. Jakarta: PT. Rineka Cipta.

Assauri, Sofjan. 2004. Manajemen Produksi dan Operasi, Edisi Revisi. Jakarta: Lembaga Penerbit Fakultas Ekonomi Universitas Indonesia.

Badan Pusat Statistik(BPS). 2013. Kota Mataram Dalam Angka. http://www.bps.go.id diunduh 10 Juli 2015.

Chase, Richard B. et.al. 2001. Operations Management for Competitive Advantage, $9^{\text {th }}$ Edition. New York: Mc Graw - Hill Companies Inc.

Corder, S.Antony. 2000. Teknik Manajemen Pemeliharaan. Jakarta: Erlangga.

Departemen Perdagangan Republik Indonesia. 2008. Rencana Pengembangan Ekonomi KreatifIndonesia 2009 - 2025. Jakarta: Departemen Perdagangan.

Departemen Perdagangan Republik Indonesia. 2009. Pengembangan Ekonomi Kreatif Indonesia. Jakarta: Departemen Perdagangan.

Gaspersz, Vincent. 2004. Total Quality Management Edisi I. Jakarta: P.T Gramedia Pustaka Utama.

Handoko, T.Hani. 2003. Manajemen, Edisi 2 Cetakan Kedelapan. Yogyakarta: BPFE Yogyakarta. 2009. Dasar-Dasar Manajemen Produksi dan Operasi. Yogyakarta: BPFE.

Hasibuan, Malayu S.P. 2003. Manajemen Sumber Daya Manusia, Edisi Revisi. Jakarta: Bumi Aksara.

Krajeski, Lee J. and Barry P. Ritzman. 2007. Operation Management Processes and Value Chains. Upper Saddle River, USA: Prantice Hall Inc.

Lewis, S. Pamela et.al. 2003. Management - Challenges For Tomorrow Leader, $4^{\text {th }}$ Edition. South West Canada: Thomson.

Ma'arif Syamsul. 2003. Manajemen Operasi. Jakarta: PT Gramedia Widiasarana Indonesia 
Nazir, Moh. 2003. Metodologi Penelitian, Cetakan Kelima. Jakarta: Ghalia Indonesia.

Prawirosentono, Suyadi. 2001. Filosofi Baru Tentang Manajemen Mutu Terpadu (Total Quality Management) Abad 21, Edisi Revisi. Jakarta: Bumi Aksara.

Sekaran, Uma. 2006. Metode Penelitian Untuk Bisnis. Jakarta: Salemba Empat

Simatupang, MT. 2008. Industri Kreatif Untuk Kesejahteraan Bangsa. ITB Bandung: Inkubator Industri dan Bisnis.

Sowter, Colin. 2001. Marknon. UK: McGraw - Hill International Limited.

Sugiyono. 2006. Metode Penelitian Kuantitatif, Kualitatif, dan RED. Bandung: Alfabeta.

Sumayang, L. 2003. Dasar-Dasar Manajemen Produksi dan Operasi. Jakarta: Salemba Empat. 